
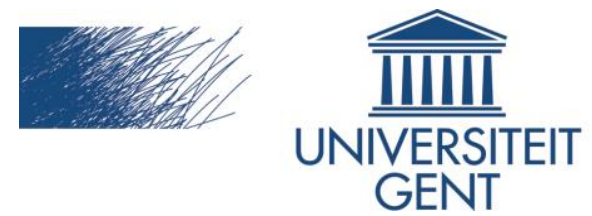

biblio.ugent.be

The UGent Institutional Repository is the electronic archiving and dissemination platform for all UGent research publications. Ghent University has implemented a mandate stipulating that all academic publications of UGent researchers should be deposited and archived in this repository. Except for items where current copyright restrictions apply, these papers are available in Open Access.

This item is the archived peer-reviewed author-version of: PEGylation of recombinant human deoxyribonuclease I decreases its transport across lung epithelial cells and uptake by macrophages

Authors: Mahri S., Hardy E., Wilms T., De Keersmaecker H., Braeckmans K., De Smedt S., Bosquillon C., Vanbever R.

In: International Journal of Pharmaceutics, 593, Article Number: 120107

To refer to or to cite this work, please use the citation to the published version:

Mahri S., Hardy E., Wilms T., De Keersmaecker H., Braeckmans K., De Smedt S., Bosquillon C., Vanbever R. (2021) PEGylation of recombinant human deoxyribonuclease I decreases its transport across lung epithelial cells and uptake by macrophages

International Journal of Pharmaceutics, 593, Article Number: 120107

DOI: 10.1016/j.ijpharm.2020.120107 


\section{PEGylation of recombinant human deoxyribonuclease I deceases its transport across lung epithelial cells and uptake by macrophages}

Sohaib Mahri ${ }^{1,2}$, Eléonore Hardy ${ }^{1}$, Tobias Wilms ${ }^{1}$, Herlinde De Keersmaecker ${ }^{3,4}$, Kevin Braeckmans $^{3,4}$, Stefaan De Smedt ${ }^{3,4}$, Cynthia Bosquillon ${ }^{2}$, Rita Vanbever ${ }^{1, *}$

1 Université catholique de Louvain (UCLouvain), Advanced Drug Delivery \& Biomaterials, Louvain Drug Research Institute (LDRI), Brussels, 1200, Belgium.

2 University of Nottingham, School of Pharmacy, Nottingham, UK.

3 Ghent University, Faculty of Pharmaceutical Sciences, Laboratory for General Biochemistry and Physical Pharmacy, 9000 Ghent, Belgium

4 Ghent University, Centre for Advanced Light Microscopy, 9000 Ghent, Belgium

*Corresponding author at: Université catholique de Louvain, Louvain Drug Research Institute, Advanced Drug Delivery and Biomaterials, Avenue Emmanuel Mounier 73, Brussels 1200, Belgium. Tel.: +32 276473 25; fax: +32 276473 98. E-mail address: rita.vanbever@uclouvain.be 


\begin{abstract}
Conjugation to high molecular weight (MW) polyethylene glycol (PEG) was previously shown to largely prolong the lung residence time of recombinant human deoxyribonuclease I (rhDNase) and improve its therapeutic efficacy following pulmonary delivery in mice. In this paper, we investigated the mechanisms promoting the extended lung retention of PEG-rhDNase conjugates using cell culture models and lung biological media. Uptake by alveolar macrophages was also assessed in vivo. Transport experiments showed that PEGylation reduced the uptake and transport of rhDNase across monolayers of Calu-3 cells cultured at an air-liquid interface. PEGylation also decreased the uptake of rhDNase by macrophages in vitro whatever the PEG size as well as in vivo $4 \mathrm{~h}$ following intratracheal instillation in mice. However, the reverse was observed in vivo at $24 \mathrm{~h}$. The uptake of rhDNase by macrophages was dependent on energy, time, and concentration and occurred at rates indicative of adsorptive endocytosis. The diffusion of PEGylated rhDNase in porcine tracheal mucus and cystic fibrosis sputa was slower compared with that of rhDNase. Nevertheless, no significant binding of PEGylated rhDNase to both media was observed. In conclusion, decreased transport across lung epithelial cells and uptake by macrophages appear to contribute to the longer retention of PEGylated rhDNase in the lungs.
\end{abstract}

\title{
Keywords
}

Recombinant human deoxyribonuclease I, PEGylation, Pulmonary delivery, Alveolar macrophages, Transport across Calu-3, Diffusion in mucus. 
Graphical abstract

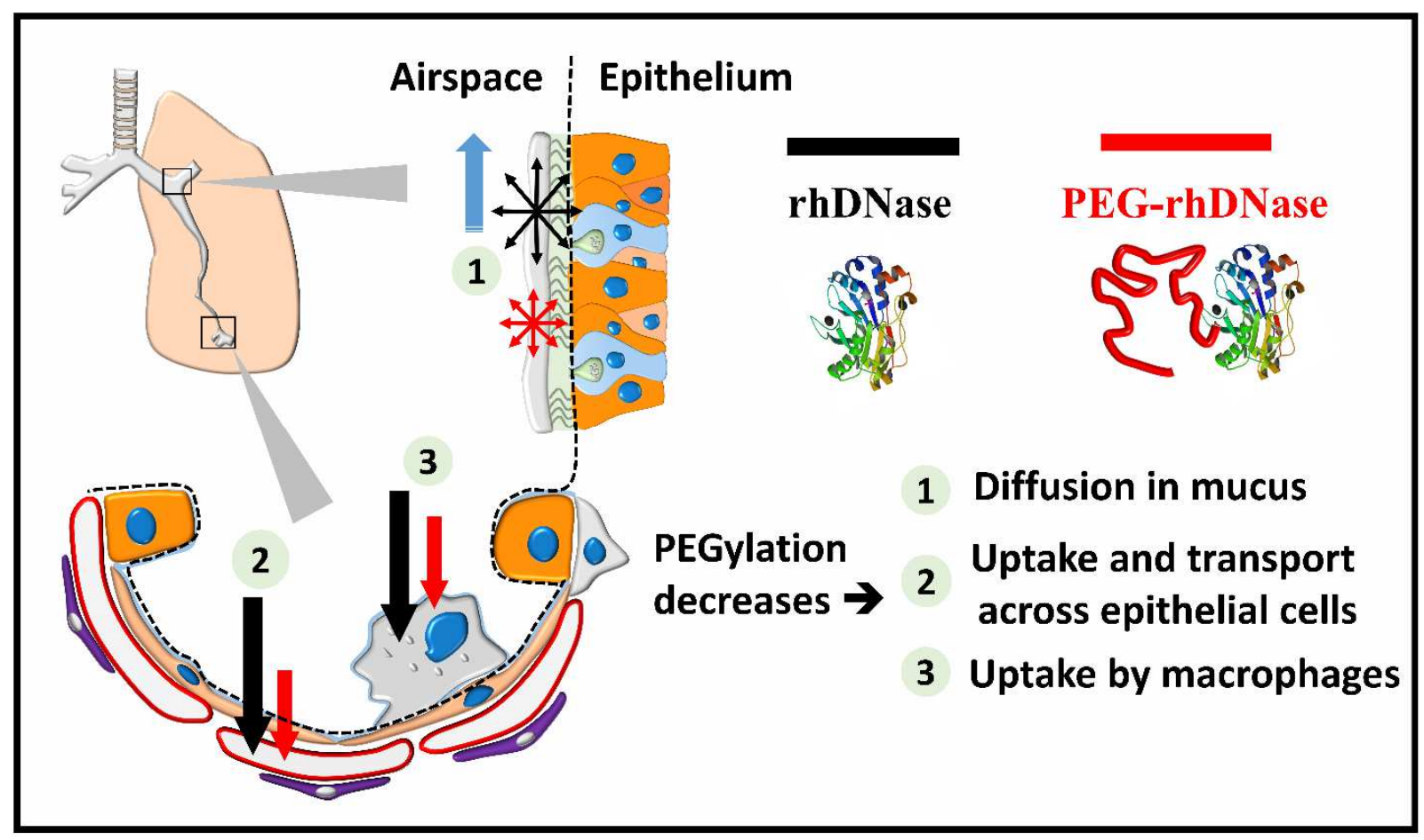




\section{Introduction}

Since the emergence of recombinant human insulin in the early 1980s, the number of therapeutic proteins never ceased to grow to our days to become a therapeutic class on their own $[1,2]$. Currently, the number of approved products with distinct active protein ingredients exceeds a couple of hundred products, and many more are in clinical trials [3].

Despite this success, therapeutic proteins face several challenges, including instability, short halflife, immunogenicity, and low penetration through biological barriers $[4,5]$. Several of these drawbacks could be overcome by conjugation to natural or synthetic polymers [4]. PEGylation, defined as the covalent coupling to polyethylene glycol (PEG) chain, is the prevailing protein modification strategy with the most clinical success so far. As per early 2020, over 15 PEGylated proteins have been approved by the FDA [6, 7]. All of them are administered by injection and none by other routes of drug administration.

Therapeutic proteins present an attractive opportunity for the treatment of respiratory diseases such as asthma, cystic fibrosis (CF), chronic obstructive pulmonary disease (COPD), alpha-1 antitrypsin deficiency, and lung cancers [8]. Local delivery to the lungs allows i) achieving high concentrations of the protein to the target, ii) promoting a rapid clinical response, and iii) administering only fractions of the doses otherwise given by parenteral routes; therefore, iv) mitigating the risk of systemic side effects $[9,10]$.

The lack of marketed PEGylated proteins for pulmonary delivery reflects the paucity of approved proteins for the inhalation route in the first place. The only approved inhaled protein for local lung delivery is the mucolytic recombinant human DNase I (rhDNase, Pulmozyme $\left.{ }^{\circledR}\right)$ for the symptomatic management of $\mathrm{CF}$ [7]. Because of its rapid clearance from the lungs, rhDNase is administered once or twice a day by nebulisation [11]. The nebulisation time of 3 to $10 \mathrm{~min}$ and the daily burden of multiple drugs taken by inhalation often limit adherence of patients with CF to their treatment. Therefore, extending the residence time of rhDNase in the lungs would be beneficial to those patients [11]. 
To our knowledge, PEGylation is the only protein conjugation strategy in the literature with tangible benefits in extending the half-life of proteins in the lungs after pulmonary delivery. Previous works have established the extended retention of PEGylated proteins in the lungs after pulmonary administration in small animals [7, 12-16]. The larger the PEG, the longer the retention [7]. Most markedly, the residence time of PEGylated rhDNase in murine lungs after intratracheal instillation was extended to over 15 days with PEGs of $30 \mathrm{kDa}$ and $40 \mathrm{kDa}$ compared with less than $24 \mathrm{~h}$ for native rhDNase [7]. PEGylation of rhDNase was also reported to enhance its thermal stability [17]. Reduced systemic absorption, mucoadhesion, decreased uptake by respiratory cells, and protection against degradation in the lungs are the main mechanisms evoked to explain the longer retention of PEGylated proteins [18].

The absorption of proteins by the lungs is influenced, to a great extent, by their molecular size and nature, and the bioavailability does not exceed, in general, $5 \%$ for large proteins (molecular weight, $\mathrm{MW} \geq 40 \mathrm{kDa}$ ) [19-21]. PEGylation has been shown to reduce the systemic absorption of recombinant human granulocyte-colony stimulating factor (rhGCSF, $18 \mathrm{kDa}$ ), IFNa2b (19 kDa), and recently rhDNase following pulmonary delivery in small animals [16, 22, 23]. The same trend has also been shown in vitro in Calu-3 human lung epithelial cells for PEGylated anti-IL-13 and anti-IL-17A ( $47 \mathrm{kDa})$ [14].

A wide range of proteins has also been shown to be captured by alveolar macrophages following pulmonary delivery in different species [24]. This uptake was shown to affect large proteins more efficiently than small proteins and peptides purportedly due to the longer presence of the formers within the airspaces [25]. Uptake of PEG and PEGylated proteins by alveolar macrophages in vivo has also been demonstrated previously [7, 12, 16, 26, 27].

Furthermore, PEGylation with large MW has been reported to confer mucoadhesion properties to Fab' antibody fragments [12, 14]. Strong adhesion to mucus hinders the diffusion and penetration of proteins through the mucus which could lead to a fast elimination in the upper airways where the mucociliary clearance is fast $[12,28,29]$. On the other hand, adhesion to mucus could be advantageous for extending the local retention of proteins in the distal airways and alveolar region where the mucociliary escalator is less efficient [12]. 
The purpose of this work was to investigate the impact of PEGylation of rhDNase on its transport across lung epithelial cells, uptake by macrophages, and interaction with respiratory mucus. We hypothesised that PEGylation of rhDNase would i) decrease its transport across epithelial cells, ii) reduce its uptake by macrophages, and iii) hinder its diffusion in respiratory mucus, thus, contributing to the longer retention of rhDNase in lung airspaces. Calu-3 cells, cultured at the airliquid interface (ALI), were used as a model to study the uptake and transport of rhDNase and PEG30-rhDNase across lung epithelia. The uptake by macrophages was assessed for rhDNase and its conjugates with PEG of $20 \mathrm{kDa}, 30 \mathrm{kDa}$, and $40 \mathrm{kDa}$ in mice and in vitro on two murine macrophage-like cell lines, interstitial J774 macrophages and alveolar MHS macrophages. Mechanistic studies were further conducted to elucidate the pathway of endocytosis. Finally, the interaction of native and PEGylated rhDNase with tracheal mucus and CF sputa was assessed by fluorescence recovery after photobleaching (FRAP). 


\section{Materials and Methods}

\subsection{Materials}

Commercial recombinant human deoxyribonuclease I (rhDNase, Pulmozyme ${ }^{\circledR}$ ) was obtained from Genentech, Inc. (South San Francisco, CA, USA). Linear methoxy PEG propionaldehyde of $20 \mathrm{kDa}$ and $30 \mathrm{kDa}$ and two-arm methoxy PEG propionaldehyde of $40 \mathrm{kDa}$ (PEG20, PEG30, and PEG40 respectively) were obtained from NOF Corporation (Tokyo, Japan). NHSRhodamine was purchased from Thermo Fisher Scientific (Gent, Belgium). Rhodamine-PEG30 was purchased form Creative PEGWorks (Winston Salem, NC, USA) with a degree of labelling (DOL) of Rhodamine $\geq 0.93$. L-lactate dehydrogenase (LDH) from rabbit muscle, rhodamine $B$ isothiocyanate-Dextran of average MW $70 \mathrm{kDa}$ (D70), albumin from human serum (96-99\%), and Fluorescein isothiocyanate-dextran of average MW $40 \mathrm{kDa}$ and $70 \mathrm{kDa}$ (FD40 and FD70 respectively) were purchased from Sigma-Aldrich (St. Louis, MO, USA). 4-(2hydroxyethyl)1-piperazineethanesulfonic acid (HEPES), Trypan Blue Solution (0.4\%), RPMI-1640 medium, Dulbecco's Modified Eagle's Medium/Nutrient Mixture F-12 Ham (DMEM- F12), and cell culture supplements were obtained from Gibco (Life Technologies, Gent, Belgium). FITC (5/6fluorescein isothiocyanate) mixed isomer was obtained from Thermofisher (Gent, Belgium). RIPA lysis buffer was purchased from Abcam (Cambridge, UK). Resource Q $1 \mathrm{~mL}$ and HiLoad 16/60 superdex 200 columns were obtained from GE Healthcare (Bio-Sciences AB, Uppsala, Sweden). Unless otherwise mentioned, other chemicals were purchased from Sigma-Aldrich (St. Louis, MO, USA).

\subsection{PEGylation of rhDNase}

rhDNase was conjugated with PEG20 kDa, PEG30 kDa, and PEG40 kDa to obtain PEG20rhDNase, PEG30-rhDNase, and PEG40-rhDNase, respectively. The PEGylation was performed by reductive amination, as previously reported $[7,11]$. Briefly, commercial rhDNase (Pulmozyme®, Genentech, Inc. CA, USA) was concentrated to $5-10 \mathrm{mg} / \mathrm{ml}$ in $1 \mathrm{mM} \mathrm{CaCl}$, $100 \mathrm{mM} \mathrm{CH} \mathrm{CO}_{2} \mathrm{Na}$ (sodium acetate buffer, $\mathrm{pH}$ 5) then added to PEG propionaldehyde at a molar ratio PEG:rhDNase of 4:1 in the presence of $34 \mathrm{mM} \mathrm{NaBH} 3 \mathrm{CN}$ (cyanoborohydride, reducing agent). The reaction mixtures were stirred at room temperature overnight. The monoPEGylated products were purified by anion exchange chromatography on a Resource Q, $1 \mathrm{~mL}$ column with $\ddot{\text { AKTA }}{ }^{\mathrm{TM}}$ purifier 10 system then by size exclusion chromatography (SEC) on HiLoad 16/60 superdex 200 column (GE Healthcare Bio-Sciences AB, Uppsala, Sweden). 
rhDNase and PEGylated rhDNase products were filtered through $0.22 \mu \mathrm{m}$ PVDF membranes, and stored at $4{ }^{\circ} \mathrm{C}$ in $150 \mathrm{mM} \mathrm{NaCl}, 1 \mathrm{mM} \mathrm{CaCl}_{2}$ as the marketed rhDNase. Successful monoPEGylation of rhDNase was previously demonstrated by our laboratory using SDS-PAGE and matrix-assisted laser desorption/ionization time-of-flight mass spectrometry [11]. The yield of the final purified mono-PEGylated rhDNase varied between $20-40 \%$ of the starting amount of rhDNase.

\subsection{Fluorescent labelling of proteins}

NHS-Rhodamine was used for labelling rhDNase, PEGylated rhDNases, albumin, and LDH. To this end, rhDNase or PEG-rhDNase products were exchanged against phosphate buffer saline (PBS, pH 7.4), $1 \mathrm{mM} \mathrm{CaCl}$, by ultrafiltration using Vivaspin ${ }^{\circledR}$ Turbo $4,3 \mathrm{kDa}$ (Sartorius; Stonehouse, Gloucestershire, UK). NHS-Rhodamine dye at $10 \mathrm{mg} / \mathrm{ml}$ in DMSO was added to protein solutions at a molar ratio dye: protein of 10:1 and the reaction mixtures were kept at room temperature in the dark under constant stirring for 1 hour. The mixtures were ridded of the excess unreacted dye by dialysis against $1 \mathrm{mM} \mathrm{CaCl}_{2}, 150 \mathrm{mM} \mathrm{NaCl}$ (Spectra/Por molecular porous membrane tubing MWCO 6-8 kD, Spectrum). Labelled proteins were further purified by SEC on HiLoad Superdex 200 pg column using $1 \mathrm{mM} \mathrm{CaCl}_{2}, 150 \mathrm{mM} \mathrm{NaCl}$ as eluent, concentrated by ultrafiltration (Vivaspin ${ }^{\circledR}$ Turbo 15, $5 \mathrm{kDa} \mathrm{MWCO}$ ), filtered through $0.22 \mu \mathrm{m}$ PVDF membranes, and stored at $4{ }^{\circ} \mathrm{C}$ in $1 \mathrm{mM} \mathrm{CaCl}_{2}, 150 \mathrm{mM} \mathrm{NaCl}$ (Figure $\mathrm{S} 1$ and S2). The same DOL of one dye molecule per protein molecule was achieved for rhDNase and PEG-rhDNase products. No detectable levels of lipopolysaccharide (LPS) were found in stock solutions of native and PEGylated rhDNase used for the in vivo experiment (Figure S3). The same labelling procedure was used for albumin and $\mathrm{LDH}$ using PBS instead of $\mathrm{CaCl}_{2}, \mathrm{NaCl}$ in all steps.

\subsection{Transport across epithelial cells}

\subsubsection{Culture of Calu-3}

Calu-3, lung adenocarcinoma epithelial cells, were purchased from the American Type Culture Collection (Rockville, MD, USA) and used between passage 32 and 37. Cells were maintained in Dulbecco's Modified Eagle's Medium/Nutrient Mixture F-12 Ham (DMEM- F12) supplemented with $10 \% \mathrm{v} / \mathrm{v}$ of FBS and $1 \% \mathrm{v} / \mathrm{v}$ of Penicillin-Streptomycin. The cell cultures 
were maintained at $37{ }^{\circ} \mathrm{C}$ in a humidified atmosphere of $5 \% \mathrm{CO}_{2}$ with medium changes every other day and passaging at $~ 80 \%$ confluency.

\subsubsection{Culture of Calu-3 on Air-Liquid Interface (ALI)}

Calu-3 cells were seeded at a density of $1 \times 10^{5}$ cell $/ \mathrm{cm}^{2}$ on Transwell@ inserts (PET, $1.12 \mathrm{~cm}^{2}$, $0.4 \mu \mathrm{m}$ pore size; Corning Life Sciences, MA, USA). Two to four days later, cells were raised to ALI by removing the medium from both apical and basolateral sides of the Transwell@ inserts and only replacing the latter with fresh medium $(500 \mu \mathrm{l})$. The medium on the basolateral side was changed every other day thereafter until the day of the experiment. Mucus was removed once a week by gentle washing by Hank's Balanced Salt Solution (HBSS). Transepithelial electrical resistance (TEER) measurements were performed using EVOM meter with chopstick electrodes (World Precision Instruments, Stevenage, UK). For this, cells were equilibrated in HBSS by adding $500 \mu \mathrm{l}$ in the apical side and $1500 \mu \mathrm{l}$ in the basolateral side. The monolayer integrity was confirmed by TEER values $\geq 450 \Omega . \mathrm{cm}^{2}$.

\subsubsection{Transport across Calu-3 cell monolayer}

On the experiment day, TEER measurements were taken, and the basolateral side was changed with $500 \mu \mathrm{l}$ of fresh medium. $5 \mu \mathrm{l}$ containing 270 picomols of rhDNase (10 $\mu \mathrm{g})$, PEG30rhDNase, D70, or PEG30 in $1 \mathrm{mM} \mathrm{CaCl}_{2}, 150 \mathrm{mM} \mathrm{NaCl}$ was applied directly on the apical side of Calu-3 cells. Transwell@ inserts were then incubated at $37{ }^{\circ} \mathrm{C}$ and $5 \% \mathrm{CO}_{2}$ without shaking. Zero, $2,4,8,12$, and $24 \mathrm{~h}$ post-exposure, $100 \mu \mathrm{l}$ of the medium was sampled from the basolateral side of each Transwell@ insert and replaced by $100 \mu \mathrm{l}$ of fresh medium. At $24 \mathrm{~h}$, the basolateral medium was recovered, and the apical side was gently washed with $\operatorname{HBSS}(2 \mathrm{x}$ $500 \mu 1)$. TEER was measured again as described above. All cell layers maintained a TEER $\geq$ $450 \Omega . \mathrm{cm}^{2}$. Finally, cells were detached with trypsin, washed, and each cell sample was divided into two parts. One half was analysed by flow cytometry (LSR Fortessa, BD Biosciences, San Jose, USA) using $561 \mathrm{~nm}$ (yellow-green laser) with at least 10,000 events recorded for each sample. The other half was lysed by adding $100 \mu$ RIPA lysis buffer, centrifuged for $10 \mathrm{~min}$ at 14,000 g at $4{ }^{\circ} \mathrm{C}$ and the supernatants were stored at $-20{ }^{\circ} \mathrm{C}$.

The concentrations of compounds in the apical side, basolateral side, or cell layers were measured by fluorescence spectrometry at 555/580 nm (ex/em) in black 384 well plates (Greiner Bio-One GmbH, Frickenhausen, Germany) against the corresponding calibration 
curves in the appropriate media (HBSS, medium, or RIPA for apical side, basolateral side, and cell layer, respectively). The cumulative quantities for compounds in the basolateral side were reported as a percentage of the initial dose (270 picomols), taking into account the amounts removed from the system during sampling. Quantities in the cell layer were expressed in picomol per mg of cell protein content. Protein content was determined by Pierce ${ }^{\mathrm{TM}}$ BCA Protein Assay Kit (Thermo Scientific ${ }^{\mathrm{TM}}$ Pierce $^{\mathrm{TM}}$, Gent, Belgium).

\subsubsection{Activity of rhDNase and PEG30-rhDNase in apical and basolateral side by methyl green assay}

The activity of rhDNase and PEG30-rhDNase in the apical and basolateral sides of the Transwell@ inserts was assessed using methyl green (MG) assay described elsewhere [11, 30]. Briefly, the hydrolysis of the DNA-methyl green substrate (DNA-MG) by deoxyribonuclease releases free MG in solution, the colour of this latter fades out to colourless with time leading to a decreased optical density (OD) at $620 \mathrm{~nm}$. Samples from the basolateral side at $4 \mathrm{~h}$ and 24 $\mathrm{h}$ were initially diluted threefold then $50 \mu \mathrm{l}$ was placed on the first column of a 96-well plate with controls of rhDNase and PEG30-rhDNase of known concentrations (16.2 nM, equivalent to $600 \mathrm{ng} / \mathrm{ml}$ of rhDNase). Samples and controls underwent further 2-fold serial dilutions on the 96-well plate then $50 \mu 1$ of DNA-MG solution was added to all wells. Plates were sealed and incubated in a humid chamber at $37^{\circ} \mathrm{C}$ for $24 \mathrm{~h}$. At the end of the incubation time, the OD was measured at $620 \mathrm{~nm}$ by SpectraMax i3 (Molecular Devices, CA, USA).

Samples from the apical side were diluted to a nominal concentration of $5.4 \mathrm{nM}$ (equivalent to $200 \mathrm{ng} / \mathrm{ml}$ of rhDNase) then analysed by MG assay. For this, $100 \mu 1$ of diluted samples were incubated with $100 \mu \mathrm{l}$ of DNA-MG solution for $6 \mathrm{~h}$ along with controls of rhDNase and PEG30rhDNase of known concentrations.

\subsubsection{Uptake by Calu-3 cells in immersion}

Calu- 3 cells were seeded in 24 -well plates at a cell density of $2 \times 10^{5}$ cell/well and incubated at $37{ }^{\circ} \mathrm{C}$ and $5 \% \mathrm{CO}_{2}$ until near-confluence. Cells were then exposed to $162 \mathrm{nM}$ of rhDNase (6 $\mu \mathrm{g} / \mathrm{ml}$ ), PEG30-rhDnase, D70, or PEG30 for $24 \mathrm{~h}$. After $24 \mathrm{~h}$ exposure, the cells were washed by DPBS (6 x $1 \mathrm{ml})$, detached, and analysed by flow cytometry as described above.

\subsection{In vivo uptake by alveolar macrophages}




\subsubsection{Animals}

All experimental protocols were approved by the Institutional Animal Care and Use Committee of the Université Catholique de Louvain (Permit number 2016/UCL/MD/019). 6-week Female RjOrl SWISS mice (Elevage Janvier, Le Genest-St-Isle, France) were kept under conventional housing conditions and were allowed at least one week of acclimation before being used for experimentation between 7 and 8 weeks of age.

\subsubsection{Intratracheal instillation}

One nmol of rhodamine-labelled LPS-free rhDNase (37 $\mu \mathrm{g})$, PEG20-rhDNase (57 $\mu \mathrm{g})$, PEG30rhDNase $(67 \mu \mathrm{g})$, or PEG40-rhDNase $(77 \mu \mathrm{g})$ were administered to mice by intratracheal instillation. Control mice received the vehicle solution $\left(1 \mathrm{mM} \mathrm{CaCl}_{2}, 150 \mathrm{mM} \mathrm{NaCl}\right)$. For instillation, mice were anaesthetised by intraperitoneal injection of ketamine/xylazine (90/10 $\mathrm{mg} / \mathrm{kg}$ ) then held in a supine position by surgical tape on an inclined board $\left(\sim 45^{\circ}\right)$. Mice were then intubated with 20G catheter (VWR International BVBA, Leuven, Belgium) using a small laryngoscope (Penn-Century ${ }^{\mathrm{TM}}$ - Model LS-2, Philadelphia, USA). $25 \pm 2 \mu$ l of compounds (containing $1 \mathrm{nmol}$ of protein) or control were administered intratracheally into the lungs using a precision syringe (100 $\mu$ l, Model 710, Hamilton, Bonaduz, Switzerland) followed by an air bolus of $200 \mu \mathrm{l}(1 \mathrm{ml}$ syringe, HSW SOFT-JECT®, VWR International BVBA, Leuven, Belgium). Immediately after instillation, mice were placed in an upright position for 20-30 seconds before being transferred back to their cage.

\subsubsection{BAL collection and flow cytometry}

4 or $24 \mathrm{~h}$ post-delivery, mice were euthanised by cervical dislocation, and bronchoalveolar lavage fluid (BAL) was collected $(4 \mathrm{x} 1 \mathrm{ml})$ using $0.1 \mathrm{mM}$ EDTA-DPBS (Dulbecco's phosphate-buffered saline, no $\mathrm{Ca}^{+2}$ or $\mathrm{Mg}^{+2}$ ). BALs were centrifuged at $300 \mathrm{~g}$ for $5 \mathrm{~min}$; then, $500 \mu \mathrm{l}$ of Ammonium-Chloride-Potassium lysing buffer (ACK Lysing Buffer, Gibco ${ }^{\mathrm{TM}}$, Life Technologies, Gent, Belgium) was added to cell pellets to lyse red blood cells. BALs were then centrifuged again (300 g for $5 \mathrm{~min}$ ). Finally, the cellular fractions were resuspended in $500 \mu \mathrm{l}$ PBA (DPBS supplemented with 1\% bovine serum albumin, BSA). Cell viability was assessed on a small subset and cells were counted using the trypan blue exclusion test on ТC20 ${ }^{\mathrm{TM}}$ Automated Cell Counter (Bio-Rad, Hercules, CA, USA). The remaining cells were incubated at $4{ }^{\circ} \mathrm{C}$ for 30 min with Allophycocyanin (APC) anti-mouse F4/80 antibody ( $1 \mu \mathrm{g}$ per 2 million 
cells/ml; Biolegend, Germany) to mark alveolar macrophages. After incubation, cells were analysed by the flow cytometer LSR Fortessa (BD Biosciences, San Jose, USA) using $561 \mathrm{~nm}$ (yellow-green laser) and $639 \mathrm{~nm}$ (red laser). 10,000 events (cells positive to F4/80) per sample were recorded. Data were analysed with FlowJo software (TreeStar, Ashland, OR, USA).

\subsection{In vitro uptake by macrophages}

\subsubsection{Cell culture of $\mathbf{J} 774$ and MHS}

Murine macrophage-like J774A.1 (ATCC® TIB67 ${ }^{\mathrm{TM}}$ ) and murine alveolar macrophages MHS (ATCC ${ }^{\circ}$ CRL-2019 ${ }^{\mathrm{TM}}$ ) were maintained at $37{ }^{\circ} \mathrm{C}$ and $5 \% \mathrm{CO}_{2}$ in RPMI-1640 medium [LGlutamine]. For J774 cells, the medium was supplemented with 10\% heat-inactivated Foetal Bovine Serum (FBS) and $100 \mathrm{U} / \mathrm{ml}$ Penicillin/Streptomycin. For MHS, the medium was supplemented with 10\% FBS and 2-mercaptoethanol at a final concentration of $0.05 \mathrm{mM}$. Cells were subcultured every 2-3 days and used at passage numbers between 12 and 20. Unless otherwise mentioned, MHS and J774 cells were seeded in 24-well plates at a cell density of $10^{5}$ cells/well and incubated overnight at $37{ }^{\circ} \mathrm{C}$ and $5 \% \mathrm{CO}_{2}$ before exposure to test compounds or controls.

\subsubsection{Effect of PEGylation and PEG size on uptake by macrophages}

MHS and J774 cells were exposed to $500 \mu \mathrm{l}$ of $162 \mathrm{nM}$ of rhDNase $(6 \mu \mathrm{g} / \mathrm{ml})$, PEG20-rhDNase, PEG30-rhDNase, or PEG40-rhDNase for $4 \mathrm{~h}$. Since there was no significant difference in the uptake of PEGylated rhDNase products in vitro at $4 \mathrm{~h}$, only the uptake of PEG30-rhDNase was further tested at $24 \mathrm{~h}$ by MHS cells. The negative control consisted of untreated cells. After incubation, the supernatants were discarded, and cells were washed $(6 \times 1 \mathrm{ml})$ with DPBS, detached by adding $150 \mu \mathrm{l}$ of $0.25 \%$ trypsin-EDTA solution, centrifuged at $300 \mathrm{~g}$ for $5 \mathrm{~min}$. Cell pellets were resuspended in PBA (DPBS, 1\% BSA) for flow cytometry analysis. 5,000 to 10,000 events were recorded for each condition on LSR Fortessa using $561 \mathrm{~nm}$ (yellow-green laser). Data were analysed with FlowJo software (TreeStar, Ashland, OR, USA).

\subsubsection{Characterisation of endocytosis pathway}

Effect of temperature. MHS and J774 were exposed to $162 \mathrm{nM}(500 \mu \mathrm{l})$ of rhDNase or PEG30rhDNase for $30 \mathrm{~min}$ either at $4{ }^{\circ} \mathrm{C}$ or $37{ }^{\circ} \mathrm{C}$ and $5 \% \mathrm{CO}_{2}$. Time was kept short (30 min) to avoid potential cell damage due to long time exposure to low temperatures. For plates incubated at 4 
${ }^{\circ} \mathrm{C}$, test compounds were prepared in pre-cooled media and cells were washed with chilled DPBS (3 x $1 \mathrm{ml})$ immediately before exposure. After incubation cells were then detached for flow cytometry analysis as described above.

Time-dependent uptake. J774 were exposed to $162 \mathrm{nM}(500 \mu \mathrm{l})$ of rhDNase or PEG30rhDNase then incubated at $37{ }^{\circ} \mathrm{C}$ and $5 \% \mathrm{CO}_{2}$ for $30 \mathrm{~min}, 1,2,4$, or $6 \mathrm{~h}$. After the incubation time, cells were harvested and analysed by flow cytometry as described above.

Concentration-dependent uptake. MHS were seeded at 2 x $10^{5}$ cell/well in 24 well-plate; next day, cells were exposed for $2 \mathrm{~h}$ to increasing concentrations $(0.94-30 \mu \mathrm{M})$ of rhDNase, human albumin, or D70 prepared in FBS-free cell culture medium. The incubation time was kept relatively short $(2 \mathrm{~h})$ to limit potential cell damage incurred by the lack of FBS in the medium. Cells were then washed with DPBS $(6 \times 1 \mathrm{ml})$ then lysed by adding $200 \mu \mathrm{l}$ of chilled RIPA lysis buffer. Plates were shaken for 10 minutes. The lysates were collected in $1.5 \mathrm{~mL}$ Eppendorf® tubes and centrifuged for $10 \mathrm{~min}$ at $14,000 \mathrm{~g}$ at $4{ }^{\circ} \mathrm{C}$ and supernatants were stored at $-20{ }^{\circ} \mathrm{C}$. The concentrations of compounds in the supernatants were determined by measuring the fluorescence at 555/580 nm (ex/em) (SpectraMax i3, Molecular Devices, CA, USA) against the corresponding calibration curve in RIPA lysis buffer. The uptake was reported in picomol of compound per mg of total protein content. Total protein content in the supernatants was measured by Pierce ${ }^{\mathrm{TM}}$ BCA Protein Assay Kit. Of note, the normal culture medium is spiked with $10 \%$ FBS and therefore abounds in albumin; the estimated concentration of albumin in the culture medium is around $1.4 \mathrm{mg} / \mathrm{ml}$, which does not differ a lot from the highest concentration of albumin in our experiments of $2 \mathrm{mg} / \mathrm{ml}(30 \mu \mathrm{M}$, albumin MW $65 \mathrm{kDa})$.

Rate of uptake is expressed in $\mu 1 / \mathrm{mg} / \mathrm{h}$. It was calculated as the slope of uptake vs concentration / exposure time (2h). Only the linear range of the slope of uptake vs concentration $(0-15 \mu \mathrm{M})$ was considered.

Similar experiment was performed by flow cytometry for rhDNase, PEG30-rhDNase, albumin, and D70. MHS cells were seeded at $0.5 \times 10^{5}$ cell/well in 48 well-plate. After $2 \mathrm{~h}$ of exposure to $0.94-30 \mu \mathrm{M}$ of compounds, cells were washed, detached, and analysed by flow cytometry as described above.

Markers of endocytosis. The uptake of rhDNase, PEG30-rhDNase, and PEG30 was compared with controls of fluid phase and adsorptive endocytosis, D70 and LDH, respectively [31, 32]. 
MHS and J774 cells were exposed to $162 \mathrm{nM}(500 \mu \mathrm{l})$ of rhDNase, PEG30-rhDNase, or controls for $4 \mathrm{~h}$ at $37{ }^{\circ} \mathrm{C}$ and $5 \% \mathrm{CO}_{2}$ then cells were harvested and analysed by flow cytometry as described above.

Possible artefacts due to the adsorption of rhDNase and PEG30-rhDNases on cells were avoided by washing the cells with $1 \mathrm{ml}$ of DPBS 3, 6, or 9 times. The washing did not have a significant impact on the uptake of rhDNase and PEG30-rhDNase by macrophages (Figure S4).

\subsection{Diffusion of proteins and dextran in porcine mucus and CF sputa}

\subsubsection{Collection of mucus and CF sputa}

Mucus was collected from the tracheas of healthy pigs obtained from a local abattoir according to the procedure previously described $[33,34]$. Briefly, tracheas pieces $(10-15 \mathrm{~cm})$ were cut longitudinally, and the inner walls were cleaned from contaminating blood and dirt then scraped gently by a spatula to collect mucus. Mucus from several tracheas was pooled in Eppendorf tubes then diluted $1: 3$ in $150 \mathrm{mM} \mathrm{NaCl}$, stirred at $4{ }^{\circ} \mathrm{C}$ for 30 minutes and centrifuged at 14 , $000 \mathrm{~g}$ at $4{ }^{\circ} \mathrm{C}$ for 15 minutes. The supernatant was then discarded, and the clean mucus was stored at $-80{ }^{\circ} \mathrm{C}$ until needed. Sputa from $\mathrm{CF}$ patients were collected by expectoration during physiotherapy and stored at $-80{ }^{\circ} \mathrm{C}$ (approved by the Ethics Committee of the Université Catholique de Louvain [UCL]; registration number: B403201422928).

\subsubsection{Protein labelling}

FITC (5/6-fluorescein isothiocyanate) was used for labelling rhDNase, PEG20-rhDNase, PEG30-rhDNase, and PEG40-rhDNase. The labelling reaction was performed in a solution of $1 \mathrm{mM} \mathrm{CaCl}_{2}$ in PBS (pH adjusted to 8.5). All other steps were carried out as described for NHSrhodamine labelling.

\subsubsection{Fluorescence recovery after photobleaching (FRAP)}

FRAP was used to measure the diffusion of FITC-labelled proteins (rhDNase, PEG20-rhDNase, PEG30-rhDNase, and PEG40-rhDNase) or dextrans (FD40 and F70) in porcine mucus. FITClabelled proteins or dextrans with stock concentrations of $2-4 \mathrm{mg} / \mathrm{ml}$ were diluted 1:10 to 1:30 in the different media. A volume of $5 \mu \mathrm{l}$ of the diluted sample was sandwiched between a microscopy glass slide and a cover glass (\# 1.5) sealed with an adhesive spacer of a $120 \mu \mathrm{m}$ 
thickness (S24737, Secure-Seal ${ }^{\text {TM }}$ Spacer, Thermofisher, Gent, Belgium) to create a 3D environment for diffusing without flow in the sample. All FRAP measurements were carried out at room temperature.

The experiments were performed on a C2 confocal laser scanning microscope (Nikon, Japan) equipped with an Apo 10x NA 0.45 objective lens (Nikon, Japan). The $488 \mathrm{~nm}$ Argon ion laser (40 mW, CVI Melles Griot, CA) was used for photobleaching and imaging. A disk with a radius of $30 \mu \mathrm{m}$ was photobleached using an intense laser beam. The laser power was adjusted to obtain a bleaching parameter $\mathrm{K}_{0}$ between 0.5 and 2 to limit the influence of the bleaching depth. A pre bleach image was taken, and fluorescence recovery due to diffusion in and out of the bleached region was imaged by a time-lapse of 30 frames with a time interval of $1 \mathrm{~s}$ or $1.6 \mathrm{~s}$ for buffer or mucus/sputa, respectively. The time interval was chosen to match the recovery speed depending on the diffusion coefficient and the bleached area. The pinhole size was set to 30 $\mu \mathrm{m}$. Between 9 and 15 technical replicates were measured of each sample, and three biological replicates were used for the mucus solution.

The diffusion coefficient (D) and the mobile fraction were calculated by fitting the fluorescence recovery data to the theoretical model developed by Braeckmans et al. [35] using in-house code in Matlab (The Matworks, Natick, MA, USA). In this model, the average fluorescence recovery inside a bleached disc with radius $w$ is described by:

$$
\frac{F(t)}{F_{0}}=1+\left(e^{-K_{0}}-1\right)\left[1-e^{\frac{-w^{2}}{2 D t}}\left(I_{0}\left(\frac{w^{2}}{2 D t}\right)+I_{1}\left(\frac{w^{2}}{2 D t}\right)\right)\right]
$$

Where $F_{0}$ is the fluorescence in the disc before bleaching, $D$ is the diffusion coefficient and $K_{0}$ is the bleaching parameter. $I_{0}$ and $I_{1}$ are modified Bessel functions of the first kind of zeroth and first order, respectively. To take a mobile fraction $k$ (and an immobile fraction $1-k$ ) into account, the equation 1 is substituted into the right part of equation 2 :

$$
\frac{F(t)}{F_{0}}=1+k\left(\frac{F(t)}{F_{0}}-1\right)
$$

\subsection{Statistics}


All statistical inferences are based on a two-sided significant level of $* \mathrm{p}<0.05, * * \mathrm{p}<0.01$, *** $\mathrm{p}<0.001$ and were carried out using GraphPad Prism version 8.00 (GraphPad Software, La Jolla California, USA).

\section{Results}

\subsection{Transport across epithelial cells}

In our previous work, we have shown that PEG30-rhDNase was absorbed systemically to a lower extent than rhDNase after intratracheal instillation in mice [16]. Here we quantified the uptake and transport of rhDNase and PEG30-rhDNase through Calu-3 cells cultured at ALI (Figure 1A) and in immersion and compared it to that of PEG $30 \mathrm{kDa}$ and dextran $70 \mathrm{kDa}$ (D70). D70 is a natural polymer with an average MW of $70 \mathrm{kDa}$, close to that of PEG30rhDNase (67 kDa).

The transport data across Calu-3 cells showed a significant decrease in the transport of PEG30rhDNase compared with rhDNase ( $<$ 0.001) (Figure 1B). At 24 h, 28\% of the apically applied amount of rhDNase was found on the basolateral side, 1.75 times higher than that of PEG30rhDNase $(16 \%)$. Both proteins were transported to a higher extent than D70 $(<2 \%)$ and PEG30 $(<1 \%)(\mathrm{p}<0.001)$.

To clarify whether rhDNase and PEG30-rhDNase remain active after transport across Calu-3 cells, we assessed the activity of both proteins in the basolateral chamber at $4 \mathrm{~h}$ and $24 \mathrm{~h}$, and on the apical side of the layers at the end of the experiment (24 h) (Figures $1 \mathrm{D}-\mathrm{F})$. After $24 \mathrm{~h}$, only $2.1 \%$ of the applied dose of rhDNase was found active in the basolateral side compared to $0.2 \%$ for PEG30-rhDNase (Figure 1C), i.e., respectively 13 to 75 times less than the protein quantities measured by spectrofluorimetry (Figure 1B). However, consistent with the data obtained by spectrofluorimetry, the concentrations of active PEG30-rhDNase on the basolateral side were significantly lower compared with those of active rhDNase both at $4 \mathrm{~h}$ and $24 \mathrm{~h}$ (Figure 1C). These data also indicate a lower degradation for rhDNase. Of note, the quantities estimated in the basolateral side at $4 \mathrm{~h}$ and $24 \mathrm{~h}$ using the enzymatic activity assay are underestimated as they do not take into account the proteins sampled at previous time points. In contrast, the activity of rhDNase and PEG30-rhDNase in the apical side was preserved after $24 \mathrm{~h}$ of cell exposure (Figure 1F). 


\section{A) Transport Set up}

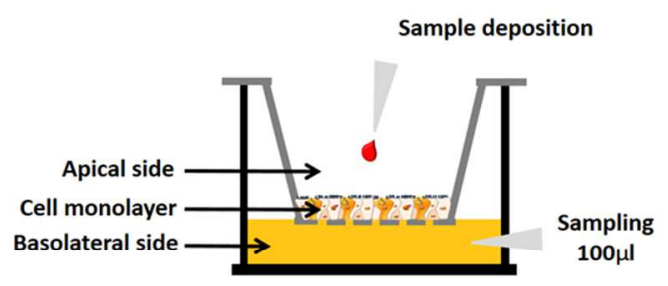

C) Basolateral side

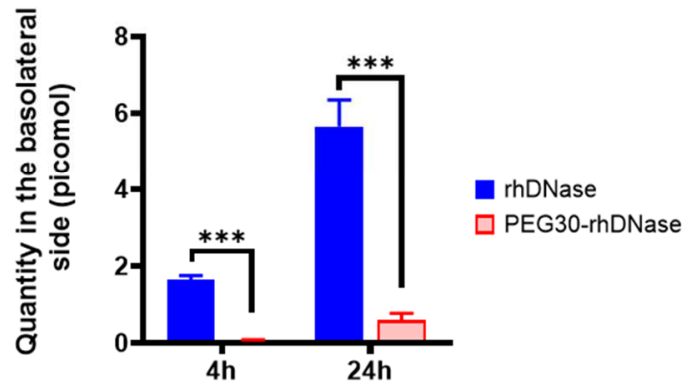

E) Basolateral side

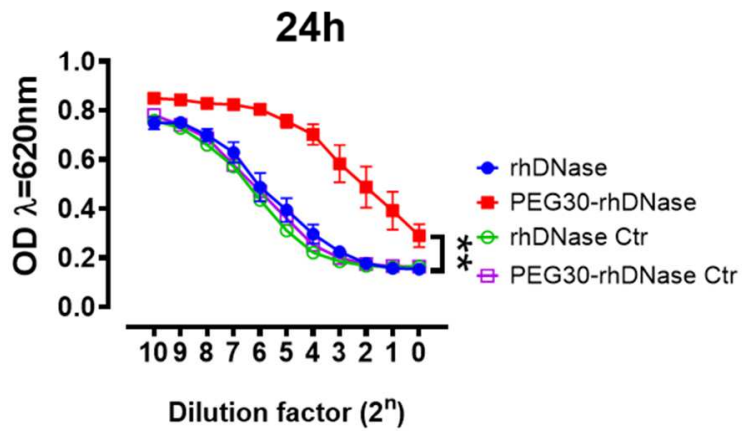

B) Cumulative transport across Calu-3

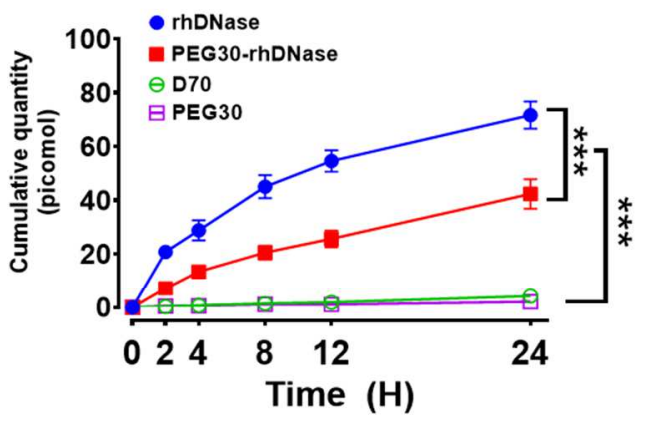

D) Basolateral side

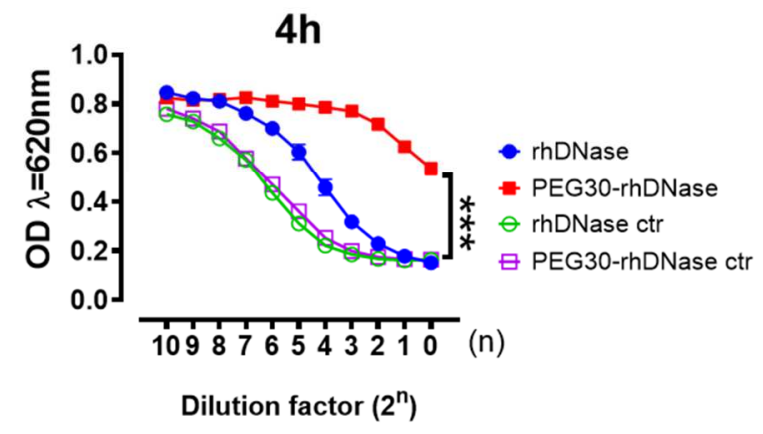

F) Apical side

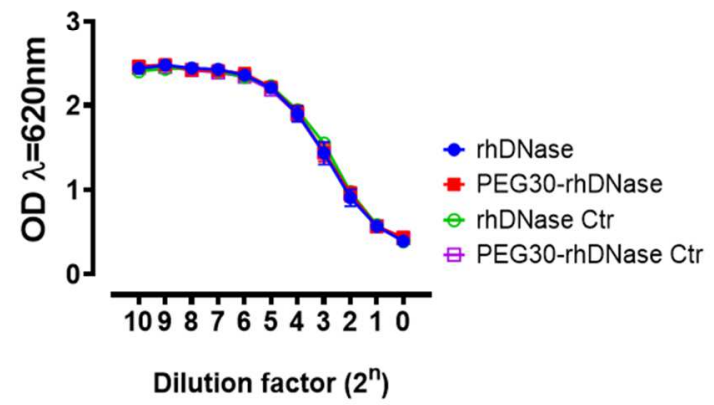

Figure 1. Transport across Calu-3 cells at the air-liquid interface (ALI). A) Culture set-up. B) Cumulative quantities in the basolateral side over time. C) Estimated quantities of rhDNase and PEG30-rhDNase in the basolateral side at $4 \mathrm{~h}$ and $24 \mathrm{~h}$ from D and E. D and E, enzymatic activity of rhDNase and PEG30-rhDNase in the basolateral side at $4 \mathrm{~h}$ (D) and $24 \mathrm{~h}$ (E) postexposure by methyl green assay. F) Enzymatic activity of rhDNase and PEG30-rhDNase in the apical side at the end of $24 \mathrm{~h}$ exposure time. Data represent mean \pm SEM ( $\mathrm{n}=6-8$ inserts). 
Significant differences among groups are presented by $*$ for $\mathrm{p}<0.05, * *$ for $\mathrm{p}<0.01$, and $* * *$ for $\mathrm{p}<0.001$ (one or two-way ANOVA, Tukey's posthoc test).

The uptake of compounds was quantified in Calu-3 cells by flow cytometry and spectrofluorimetry at the end of the exposure time $(24 \mathrm{~h})$. The amounts detected in cells were very low and presented less than $0.12 \%$ of the applied dose for rhDNase, roughly 4 times higher than that PEG30-rhDNase, F70, and PEG30 ( $<$ < 0.01) (Figure 2A and B). The amounts of active proteins in the basolateral side (Figure 1C) were 5 to 16 times those in the cell layer for PEG30-rhDNase and rhDNase, respectively.
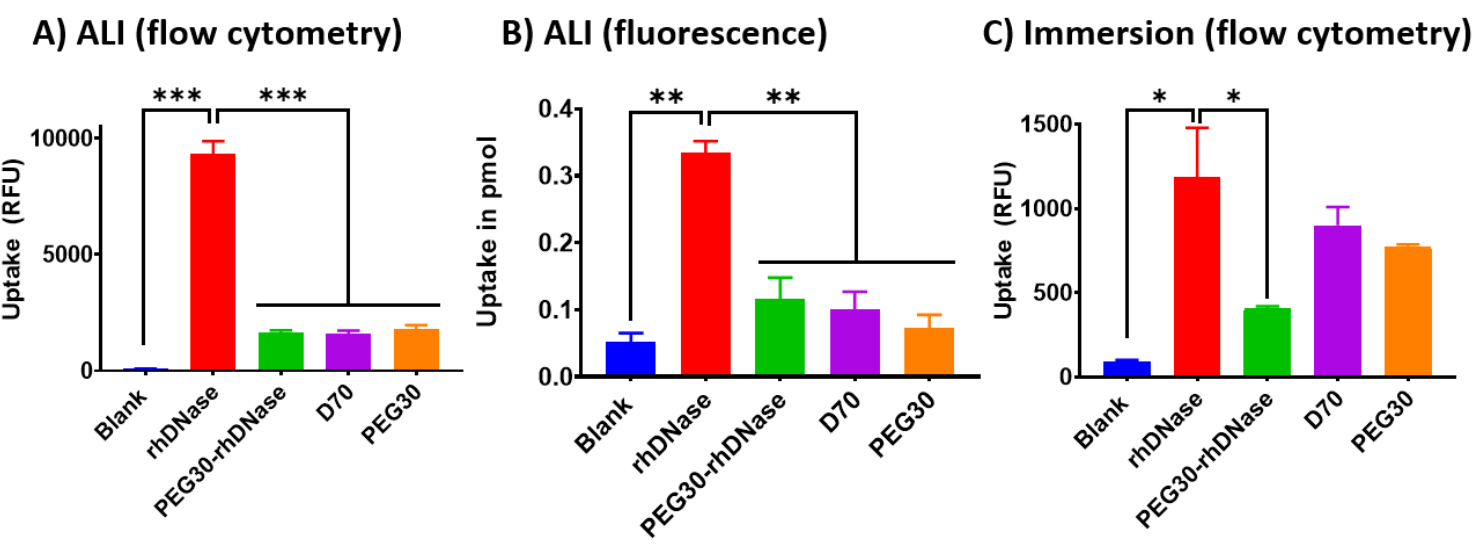

Figure 2. Uptake by Calu-3 cells at the air-liquid interface (ALI) and in immersion. Calu-3 were cultured at ALI for $22 \pm 2$ days then exposed to 270 picomols of rhodamine-labelled rhDNase $(10 \mu \mathrm{g})$, PEG30-rhDNase, dextran, or PEG30. $24 \mathrm{~h}$ later cells were detached by trypsin then half of the cells were analysed by flow cytometry (A), and the other half were lysed by RIPA lysis buffer (B), and compounds were quantified in the supernatant by spectrofluorimetry $(555 / 580 \mathrm{~nm})$. C) Calu-3 were cultured in immersion to confluency; cells were exposed to $270 \mathrm{nM}$ of rhDNase, PEG30-rhDNase, D70, and PEG30; 24 h post-exposure, cells were detached by trypsin and analysed by flow cytometry. Bars represent mean \pm SEM ( $n$ = 3-8). Significant differences among groups were checked by one-way ANOVA, Tukey's posthoc test, $*$ for $\mathrm{p}<0.05$ and $* * *$ for $\mathrm{p}<0.001$. RFU, relative fluorescence units.

Exposing Calu-3 to low concentrations of compounds in immersion only showed a significant difference between rhDNase and PEG30-rhDNase $(p<0.05)$, the uptake of this latter was threefold lower than the former $(\mathrm{p}<0.05)$ (Figure 2C). The uptake of D70 and PEG30 was not statistically significant from that of PEG30-rhDNase or rhDNase. 


\subsection{Influence of PEGylation and PEG size on the uptake of rhDNase by macrophages}

Preceding reports have highlighted the role of alveolar macrophages in the sequestration and clearance of proteins, PEGylated or not, after pulmonary delivery [12, 23, 27]. The contribution of alveolar macrophages in the uptake of native and PEGylated rhDNase was also suggested in vivo in our laboratory $[7,16]$. Here we further investigated the impact of PEGylation and PEG size on the uptake of native and PEGylated rhDNase by alveolar macrophages in vivo and in vitro on two macrophage cell lines (J774 and MHS). The mechanism of uptake was then studied and compared with markers of fluid-phase and adsorptive endocytosis.

A) In vivo uptake by alveolar macrophages
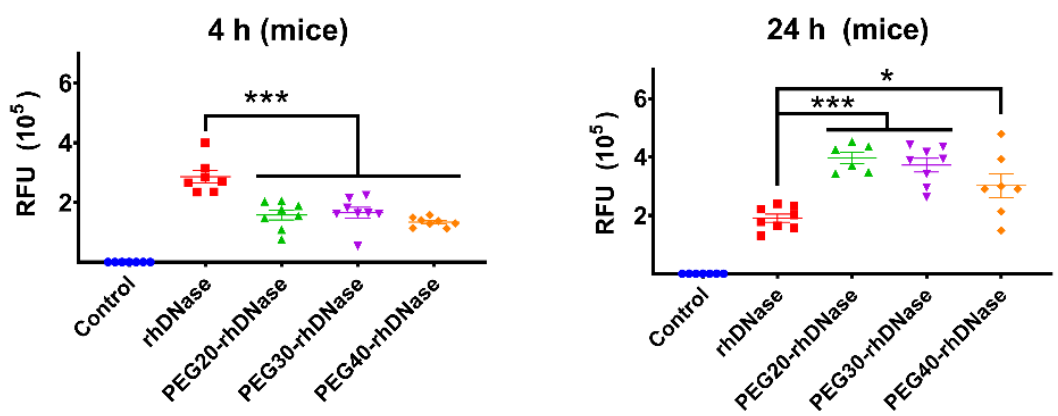

B) In vitro uptake by MHS and $\mathbf{J 7 7 4}$
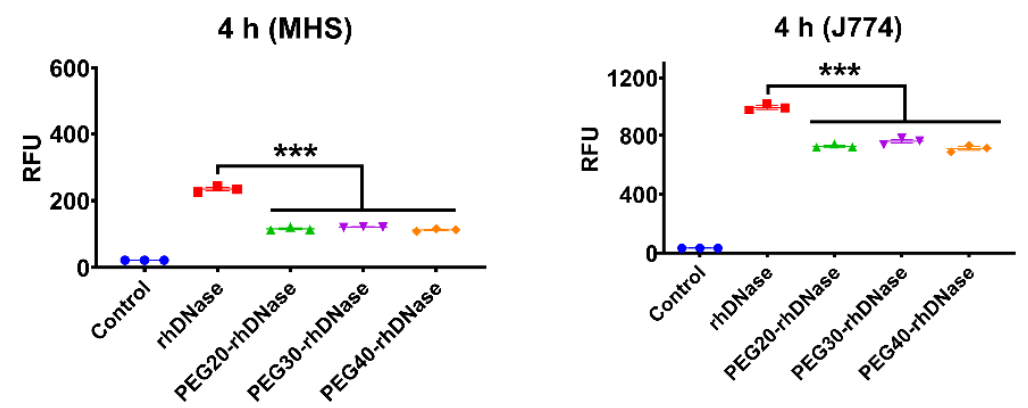

$24 \mathrm{~h}$ (MHS)

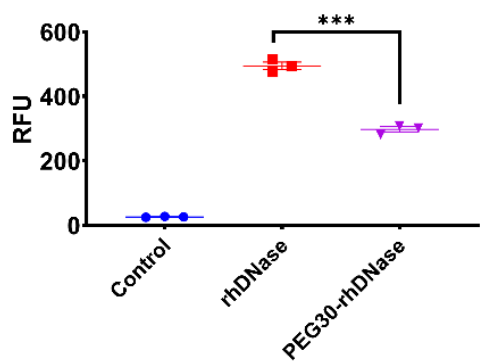

Figure 3. In vivo and in vitro uptake of rhDNase and PEGylated rhDNase by macrophages. A) In vivo uptake by alveolar macrophages. B) In vitro uptake by J774 and MHS macrophages; 
cells were exposed to $162 \mathrm{nM}$ of compounds (equivalent to $6 \mu \mathrm{g} / \mathrm{ml}$ of rhDNase) for $4 \mathrm{~h}$ or 24 $\mathrm{h}$ at $37{ }^{\circ} \mathrm{C}$ and $5 \% \mathrm{CO}_{2}$ then cells were washed, detached, and analysed by flow cytometry ( $\mathrm{n}=$ 3); control represents cells in the culture medium. Data represent individual values of median fluorescence intensities, and horizontal lines represent mean \pm SEM. Significant differences among groups were checked by one-way ANOVA, Tukey's posthoc test * for $\mathrm{p}<0.05$ and *** for $\mathrm{p}<0.001$. RFU, relative fluorescence units.

Regardless of the PEG size, the uptake of PEGylated rhDNase by alveolar macrophages was lower compared with rhDNase at $4 \mathrm{~h}$ post-intratracheal instillation in mice $(\mathrm{p}<0.001$; Figure 3A). The uptake of rhDNase was roughly double that of PEG20-rhDNase, PEG30-rhDNase, and PEG40-rhDNase. The opposite was observed $24 \mathrm{~h}$ post-delivery where the content of rhDNase within the macrophages was almost half that of PEGylated rhDNase $(\mathrm{p}<0.05)$. Interestingly the amounts of rhDNase associated with the alveolar macrophages at $24 \mathrm{~h}$ were even less than those at $4 \mathrm{~h}(\mathrm{p}<0.001)$. No significant difference among the three PEGylated products of rhDNase could be inferred neither at $4 \mathrm{~h}$ nor at $24 \mathrm{~h}(\mathrm{p}>0.05)$. Cell viability in BAL, assessed by trypan blue exclusion assay, was above $90 \%$ and was similar for all groups and time points (Figure S5).

The uptake of rhDNase and PEG-rhDNases were also assessed in vitro in two murine macrophage cell lines, MHS (alveolar) and J774 (ascites' derived) (Figure 3B). Consistent with in vivo observations, the uptake of PEG-rhDNases was less than that of rhDNase at $4 \mathrm{~h}$ in both cells lines $(p<0.001)$, with no significant difference according to the PEG size $(p>0.05)$. The decrease was more marked in MHS compared with J774 cells (2-fold vs 1.4-fold), albeit the uptake was overall higher in J744. Since there was no significant difference in the uptake of PEGylated rhDNase products by both MHS and J774 cells at $4 \mathrm{~h}$, only PEG30-rhDNase was chosen to carry out the uptake at $24 \mathrm{~h}$ by MSH cells. As expected, and contrary to what was observed in vivo at $24 \mathrm{~h}$, the uptake of PEG30-rhDNase by MHS cells was lower than that of rhDNase at $24 \mathrm{~h}(\mathrm{p}<0.001)$, consistent with the trend seen at $4 \mathrm{~h}$.

\subsection{Characterisation of endocytosis by macrophages for native and PEGylated rhDNase}


Since no significant difference in the uptake of the PEGylated forms of rhDNase was observed, only PEG30-rhDNase was selected to further investigate the mechanisms of uptake by macrophages in vitro.

The effect of temperature was tested by comparing the uptake of rhDNase and PEG30-rhDNase by $\mathrm{J} 774$ and MHS cells at $4{ }^{\circ} \mathrm{C}$ and $37^{\circ} \mathrm{C}$. After a short incubation time of $30 \mathrm{~min}$ at low temperature, the uptake of both rhDNase and PEG30-rhDNase dropped by 4-5 fold compared with that at $37^{\circ} \mathrm{C}$ in both cell lines ( $<<0.01$; Figure $\left.4 \mathrm{~A}\right)$.

The uptake was also quantified in $\mathrm{J} 774$ cells at $37^{\circ} \mathrm{C}$ up to $6 \mathrm{~h}$. The uptake was time-dependent for both proteins and significantly lower for PEG30-rhDNase in comparison with rhDNase (Figure 4B). The uptake of rhDNase, PEG30-rhDNase, albumin, and D70 was additionally studied over a range of concentrations up to $30 \mu \mathrm{M}$ at $37{ }^{\circ} \mathrm{C}$ in FBS-free medium (to avoid the potential competition of FBS with the uptake of the studied serum albumin). Note that albumin is present in the alveolar surface fluid of healthy lungs [36] and it has been used as a marker for both adsorptive and fluid phase endocytosis [37-41], while D70 is a well-established marker of fluid phase endocytosis $[42,43]$.

The uptake of rhDNase, albumin, and D70 was concentration-dependent and significantly higher for albumin and rhDNase compared with PEG30-rhDNase, and D70 ( $p<0.001)$ (Figures $4 \mathrm{C}$ and S6). The uptake of D70 was linear with concentration $\left(\mathrm{R}^{2}=0.99\right)$; however, that of rhDNase and albumin showed a saturation trend at the highest concentrations ( $30 \mu \mathrm{M})$. All compounds exhibited low rates of uptake: $5.91 \mu \mathrm{l} / \mathrm{mg} / \mathrm{h}$ (95\% CI, 5.22-6.60) for albumin, 4.18 $\mu \mathrm{l} / \mathrm{mg} / \mathrm{h}(2.92-5.44)$ for rhDNase, and $1.36 \mu \mathrm{l} / \mathrm{mg} / \mathrm{h}$ (1.13-1.59) for D70 (Figure S6).

To have more insights into the mechanisms of uptake of rhDNase, D70 and LDH (a known marker of adsorptive endocytosis which, at the $\mathrm{pH}$ of the cell culture medium, is positively charged due to its isoelectric point, pI 7.7) were tested in J774 and MHS cells [31, 32] (Figure 4D). Fluid phase endocytosis is a process by which macrophages probe fluids from the surrounding microenvironment [44]. It is a slow non-specific process that does not require binding to the cell membrane compared with adsorptive endocytosis which is also a nonspecific process, however, occurs at higher rates than fluid-phase endocytosis and involves adsorption to the cell surface $[32,45,46]$. The uptake of rhDNase was twice that of PEG30rhDNase, 3 times higher than D70 and only a third that of LDH in MHS. A similar trend was 
found in J774 except that the uptake of PEG30-rhDNase was only 0.9 that of rhDNase, and LDH was 2.5 fold higher than rhDNase.

\section{A) Temperature}

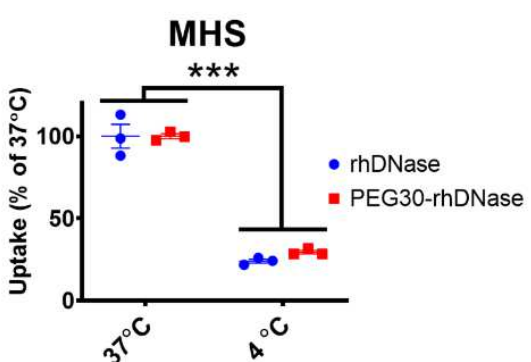

B) Time

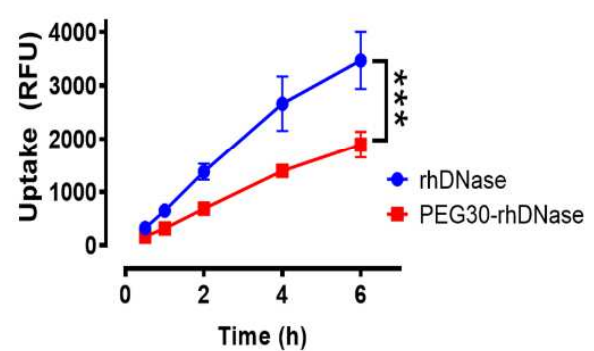

D) Markers of fluid phase and adsorptive endocytosis

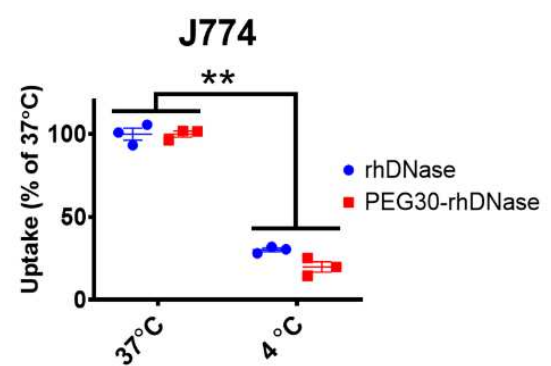

C) Concentration

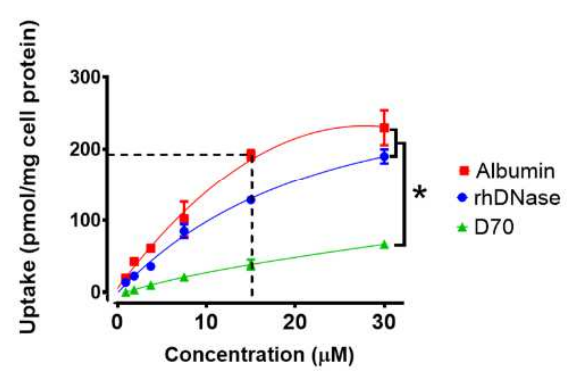

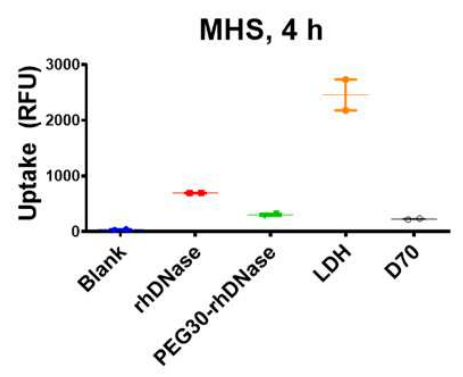

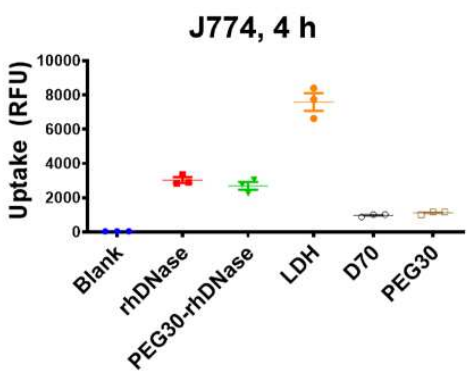

Figure 4. Endocytosis mode involved in rhDNase uptake by macrophages. A) Effect of temperature on the uptake of rhodamine-labelled rhDNase and PEG30-rhDNase in J774 and MHS macrophages; cells were exposed to $162 \mathrm{nM}$ of either compound at $37{ }^{\circ} \mathrm{C}$ or $4{ }^{\circ} \mathrm{C}$ for 30 min; Data were normalised to median fluorescence signal at $37{ }^{\circ} \mathrm{C}$. B) Time-dependent uptake of $162 \mathrm{nM}$ of rhDNase and PEG30-rhDNase $(162 \mathrm{nM})$ by $\mathrm{J} 774$ at $37^{\circ} \mathrm{C}$. C) Concentrationdependent uptake by MHS; cells were exposed to increasing concentrations $(0.94-30 \mu \mathrm{M})$ of 
rhodamine-labelled rhDNase, albumin, or D70 in the absence of FBS in the medium for $2 \mathrm{~h}$; Cells were then washed, lysed by RIPA and concentrations of compounds were measured in the supernatants by spectrofluorimetry $(555 / 580 \mathrm{~nm})$. D) Controls of fluid phase and adsorptive endocytosis; J774 and MHS macrophages were exposed to $162 \mathrm{nM}$ of rhodamine-labelled rhDNase, PEG30-rhDNase, LDH, D70, or PEG30 at $37{ }^{\circ} \mathrm{C}$ and $5 \% \mathrm{CO}_{2}$ for $4 \mathrm{~h}$. In $\mathrm{A}, \mathrm{B}$, and D, cells were washed by DPBS, detached, and analysed by flow cytometry ( $561 \mathrm{~nm}$ laser). Data represent individual values, and horizontal lines represent mean \pm SEM. Significant differences among groups were checked by one-way ANOVA, Tukey's posthoc test, * for $\mathrm{p}<0.05$ and $* * *$ for $\mathrm{p}<0.001$. RFU, relative fluorescence units.

\subsection{Diffusion in mucus and CF sputa}

To determine if PEGylation affected the diffusion and binding of rhDNase to the respiratory mucus, we assessed the diffusion of native and PEGylated rhDNase by fluorescence recovery after photobleaching (FRAP) in porcine tracheal mucus and CF sputa. Dextran of $40 \mathrm{kDa}$ (FD40) and $70 \mathrm{kDa}$ (FD70) were used as controls to assess the impact of MW and macromolecule nature on the diffusion.

A)

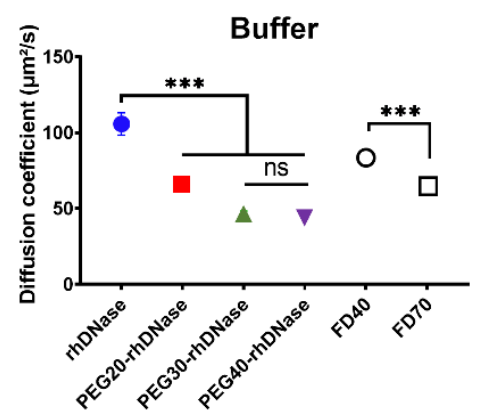

D)

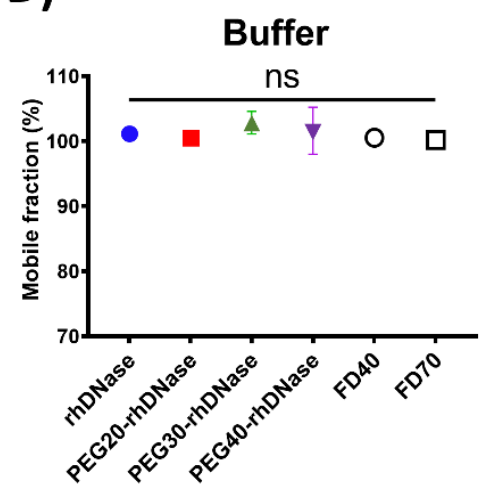

B)

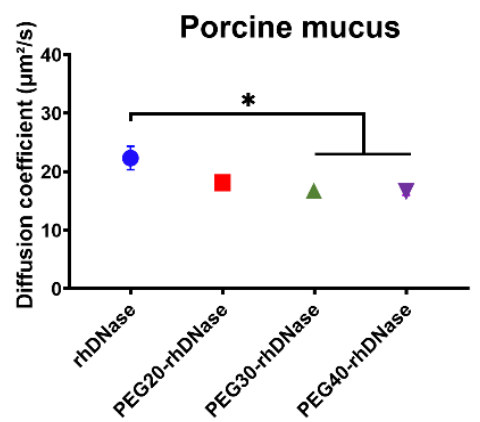

E)

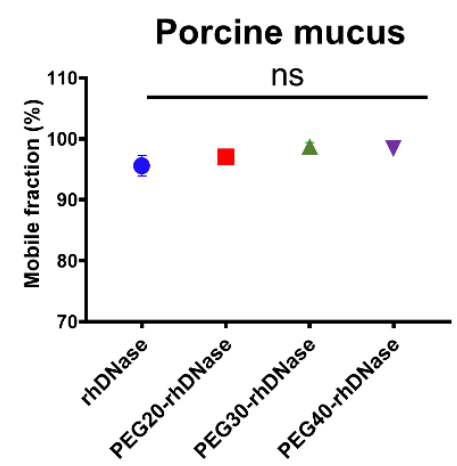

C)

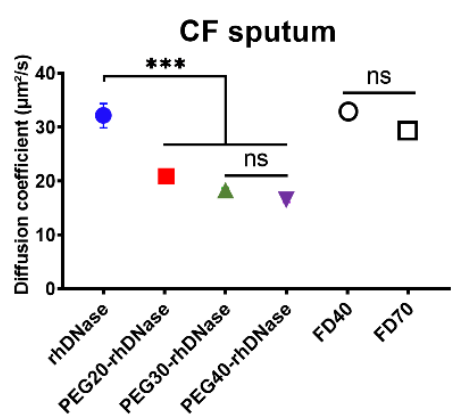

F) CF sputum

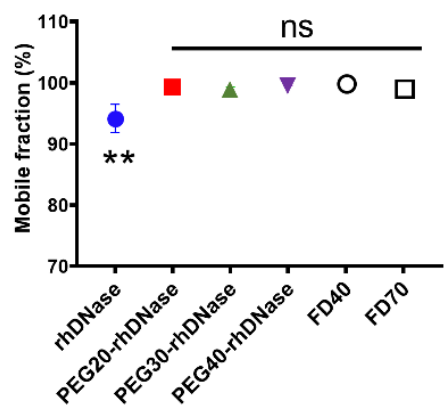


Figure 5. Diffusion of FITC-labelled native and PEGylated rhDNase and dextrans through porcine tracheal mucus, CF sputum and buffer by fluorescence recovery after photobleaching (FRAP). Diffusion coefficient $\left(\mu \mathrm{m}^{2} / \mathrm{s}\right)$ and mobility (\%) respectively in buffer (A, D), porcine mucus $(B, E)$, or CF sputa $(C, F)$. Data represent mean \pm SEM different mucus samples $(n=3)$. Significant differences among groups are presented by $*$ for $\mathrm{p}<0.05, * *$ for $\mathrm{p}<0.01$, and $* * *$ for $\mathrm{p}<0.001$ (one-way ANOVA, Tukey's posthoc test).

The diffusion of native rhDNase was faster than that of PEGylated rhDNase in all media (buffer, porcine mucus, and CF sputa) with no difference in diffusion rate observed between PEG30rhDNase and PEG40-rhDNase (Figure 5 A-C). The diffusion of all compounds was slowed down in the porcine mucus and $\mathrm{CF}$ sputum compared to the buffer (Figure 5B and $\mathrm{C}$ ). The diffusion of rhDNase in porcine mucus was 4.8 -fold slower compared with the buffer, whereas it was 3.7, 2.9, and 2.7 fold slower for PEG20-rhDNase, PEG30-rhDNase, and PEG40-rhDNase respectively (Table S1). All compounds diffused freely with no binding to the media (100\% mobile fraction) at the exception of rhDNase, whose mobile fraction was lower (94\%) in CF sputum $(\mathrm{p}<0.01 ;$ Figure 5D-F).

Transport experiments across a thin layer of porcine tracheal mucus spread at the surface of Transwell ${ }^{\circledR}$ inserts (Figure S7) showed that the half-lives (the time needed for 50\% of the initial dose to cross the mucus layers mounted on inserts) for crossing the mucus layer were qualitatively in line with the FRAP experiments. The half-lives were 24 (95\% CI, 23-26), 47 (44-51), 56 (52-61), and 60 (55-65) minutes for rhDNase, PEG20-rhDNase, PEG30-rhDNase, and PEG40-rhDNase, respectively.

\section{Discussion}

Recently, a long-acting version of rhDNase was proposed for the treatment of CF consisting of conjugated rhDNase to PEGs of $30 \mathrm{kDa}$ or $40 \mathrm{kDa}$ [7]. Here, we investigated potential mechanisms for the longer retention of PEGylated rhDNase in the lungs, namely, lower transport across epithelial cells, decreased uptake by alveolar macrophages, and adhesion to the respiratory mucus. 
Transport across Calu-3 monolayers to the basolateral side was lower for PEG30-rhDNase compared with that of rhDNase. The activity of rhDNase and PEG30-rhDNase was preserved on the apical side but largely lost on the basolateral side indicating a significant degradation of both proteins during transport. Both rhDNase and PEG30-rhDNase were transported to a higher extent than D70 and PEG30. These findings point towards a rather significant contribution of transcellular transport; however, paracellular transport cannot be dismissed.

Proteins could be absorbed through epithelial cells transcellularly in endocytic vesicles, paracellularly through tight junctions or both $[19,36]$. We propose that PEGylation with large PEGs could reduce transport by both pathways. PEGylated proteins are more hydrophilic than their corresponding unconjugated proteins, therefore, likely to interact less with the cell membrane or membrane receptors and thus not be as effectively taken up by cells. On the other hand, the relatively small size of rhDNase $(37 \mathrm{kDa}, \sim 4.8 \mathrm{~nm})$ suggests that it could be transported by the paracellular route more efficiently than the larger PEG30-rhDNase $(67 \mathrm{kDa}$, $\sim 10 \mathrm{~nm}$ ) [16]. This suggestion is based on the general assumption that proteins smaller than 40 $\mathrm{kDa}$ or 5-6 $\mathrm{nm}$ in size can diffuse through small pores in lung epithelia $[21,36]$; however, the presence of pores of 5-12 $\mathrm{nm}$ in diameter and even larger was suggested in intact alveolar epithelium and lung epithelial cell monolayers [36, 43, 47].

These findings are in line with our previously published work where both intact rhDNase and PEG30-rhDNase were absorbed into the blood after intratracheal instillation in mice, however, to a lower extent for the latter [16]. Patil et al. have also demonstrated that PEGylation of antiIL-13 and anti-IL-17A with PEG40 kDa reduced their uptake and transport across Calu-3 cells cultured at ALI [14]. Furthermore, the bioavailability of PEG $12 \mathrm{kDa}$ conjugates of IFN $\alpha 2 \mathrm{~b}$ (19 $\mathrm{kDa})$ and rhGCSF (18 $\mathrm{kDa})$ were respectively 3 and 10-fold lower compared with their unconjugated counterparts after pulmonary delivery in rats [22, 23].

While PEGylation has been shown to promote particle evasion from macrophages [48-50], such an effect has not been shown conclusively for PEGylated proteins, although a reduced macrophage uptake of PEGylated Fab' fragments has been suggested [12]. Direct quantification of proteins (PEGylated or not) in alveolar macrophages recovered by BAL following pulmonary delivery did not exceed $3 \%$ of the administered doses [7, 23, 27]. However, this percentage is probably largely underestimated because BAL only recovers a small fraction $(10 \%)$ of alveolar macrophages [27]. On the other hand, a more significant contribution of 
alveolar macrophages was suggested by Lombry et al. who reported a 3-fold increase in the bioavailability of human chorionic gonadotropin hCG (from 17.6\% to 59.7\%) after depleting alveolar macrophages from rat lungs [25].

Regardless of the PEG size, the uptake of PEGylated rhDNase was half that of rhDNase by macrophages in vitro and $4 \mathrm{~h}$ post-delivery in vivo. Surprisingly, a higher concentration of PEGylated rhDNase associated with the macrophages was measured $24 \mathrm{~h}$ post-delivery in vivo, opposite to what was obtained in vitro in MHS cells at the same time point (Figure 3B). This observation could be attributed to (i) the prolonged presence of PEG30-rhDNase in lungs airspaces and, therefore, more availability for macrophage uptake, and (ii) potentially, the higher resistance of PEGylated rhDNase to degradation within macrophages $[18,27]$. The former suggestion was confirmed in vitro where the uptake of rhDNase at $24 \mathrm{~h}$ was higher than that of PEG30-rhDNase in MHS cells. Similarly, higher amounts of PEGylated rhDNase and Fab' fragments were detected in alveolar macrophages in vivo $24 \mathrm{~h}$ post-delivery compared to their corresponding non-PEGylated counterparts [7, 27].

The uptake of rhDNase in vitro was energy, time, and concentration-dependent. Unlike that of dextran, the uptake of both rhDNase and albumin reached saturation at the highest concentration $(30 \mu \mathrm{M})$, which is more in favour of adsorptive endocytosis. Because both albumin (pI 4.7) and rhDNase (pI 4.58) are negatively charged at a neutral $\mathrm{pH}$, they are unlikely to interact strongly with either negatively charged or hydrophobic sites on the cell surface [51]. Both rhDNase and albumin could be adsorbed to the cell surface, albeit weakly compared with more positively charged (e.g., LDH) or hydrophobic proteins. According to this assumption, the hydrophilic nature of PEG could decrease the adsorption of rhDNase onto the cell membrane and, therefore, decreases its uptake by macrophages. In fact, Yamamoto et al. have shown that the PEGylation of lipid membranes prevented the adsorption of bovine serum albumin [52]. Likewise, we expect the PEGylated proteins to be less adsorbed onto lipid cell membranes.

Because macrophages are more efficient in scavenging protein aggregates [19], the lower uptake of PEG30-rhDNase by alveolar macrophages at $4 \mathrm{~h}$ in vivo could be partly ascribed to the protective effect of PEG against the aggregation of rhDNase in contact with lung lining fluids. However, preservation of the full enzymatic activity in vitro on the apical side of Calu3 layers also suggests no aggregate formation. Moreover, in a recent work, we have shown that the PEGylation only confers slight protection to rhDNase against aggregation and loss of 
activity in contact with BAL in the absence, but not the presence, of calcium ions [16]. Therefore, we conclude that the decreased uptake of PEGylated rhDNase by alveolar macrophages might not be related to protection against aggregation.

The diffusion of PEGylated rhDNase through porcine mucus and CF sputa was, as expected, slower than that of native rhDNase due to the increased hydrodynamic diameter of PEG conjugates. Mechanical trapping of proteins and dextrans in the mesh-like network of mucus is unlikely due to the large pore size of tracheal mucus (20 $\mathrm{nm}$ to several micrometres $[53,54])$ relative to the size of our tested compounds $(\leq 10 \mathrm{~nm})$. It is, however, possible that this hindrance is partially caused by the high crosslinking and tortuous pathways of concentrated mucus and purulent CF sputa $[35,55]$.

FRAP measurements of the mobility of PEGylated rhDNase and dextrans in porcine mucus indicate no strong chemical interaction of these compounds with the mucus. rhDNase, on the other hand, exhibited a slight decrease in the mobile fraction in porcine mucus and CF sputa (4\% and $6 \%$, respectively) likely due to binding to mucus components, although we cannot speculate on the nature of these interactions. Moreover, the diffusion rates of proteins in porcine mucus and CF sputa were 2.7 to 4.8 times slower than that in the buffer. The larger the PEG the least this diffusion was slowed in mucus compared to buffer. These data indicate that longer PEG chains might be more efficient in preventing interactions with mucus constituents. Contrary to our finding, the conjugation to $20 \mathrm{kDa}$ and $40 \mathrm{kDa}$ PEGs was shown to cause binding of Fab' fragments to the mucus; this adhesion was attributed to the entanglement of PEG with the mucin fibres $[12,14]$.

Finally, the mucus layer covering the airway epithelium is $2-55 \mu \mathrm{m}$ thick $[50,56]$. It is thin to absent in the lung periphery and thicker in the upper airways. Thus, the rapid diffusion rate of native and PEGylated rhDNase in mucus $(16-32 \mu \mathrm{m} 2 / \mathrm{s}$, Figure $5 \mathrm{~B}$ and $\mathrm{C})$ means that they can penetrate the mucus almost instantly and that PEGylation would not significantly impact the mucociliary clearance of rhDNase based solely on this criterion.

\section{Conclusions}


In this work, we have shown that the prolonged presence of PEGylated rhDNase in the lungs is likely promoted by lower absorption through epithelial cells and decreased uptake by alveolar macrophages as compared to the native protein. On the other hand, altered binding to airway mucus does not appear to be a notable factor affecting its fate in the lungs.

\section{Acknowledgements}

The authors would like to thank Francine Uwambayinema from Louvain Centre for Toxicology and Applied Pharmacology for providing the MHS cells (LTAP, UCLouvain, Brussels) and Safar Alqahtani for his help in setting up the Transwell@ system for the mucus transport studies. This work was a thesis project funded by the European Commission, Education, Audiovisual and Culture Executive Agency (EACEA), Erasmus Mundus programme, NanoFar doctorate (EMJD NanoFar - ref.520170-1-2011-1-FR-ERA MUNDUS-EMJD). This work was also supported by a complementary scholarship "bourse du Patrimoine”, UCLouvain, Belgium. Rita Vanbever is Research Director of the Fonds National de la Recherche Scientifique (Belgium).

\section{Conflicts of interest}

The authors report no conflict of interest.

\section{Abbreviations}

BAL, bronchoalveolar lavage; BSA, bovine serum albumin; CF, cystic fibrosis; D70, rhodamine B isothiocyanate-Dextran of average MW 70 kDa; DMEM, Dulbecco's Modified Eagle Medium; DOL, degree of labelling; DPBS, Dulbecco's phosphate-buffered saline, FD40, fluorescein isothiocyanate-dextran of average MW $40 \mathrm{kDa}$; FD70, fluorescein isothiocyanatedextran of average MW $70 \mathrm{kDa}$; HBSS, Hank's Balanced Salt Solution; HEPES, 4(2hydroxyethyl)-1-piperazineethanesulfonic acid; LDH, L-lactate dehydrogenase; MG, methyl green; pI, isoelectric point; MW, molecular weight; OD, optical density; PBA, DPBS with 1\% BSA; PBS, phosphate buffer saline; PEG, polyethylene glycol; PEG20, linear 20 kDa polyethylene glycol; PEG30, linear 30 kDa polyethylene glycol; PEG40, two-armed 40 kDa polyethylene glycol; RFU, relative fluorescence unit; rhDNase, recombinant human 
deoxyribonuclease I; SEC, size exclusion chromatography; SEM, standard error of the mean; TEER, transepithelial electrical resistance. 


\section{References}

1. Carter, P.J., Introduction to current and future protein therapeutics: A protein engineering perspective. Experimental Cell Research, 2011. 317(9): p. 1261-1269. DOI: 10.1016/j.yexcr.2011.02.013.

2. Walsh, G., Biopharmaceutical benchmarks 2014. Nature Biotechnology, 2014. 32(10): p. $992-$ 1000. DOI: 10.1038/nbt.3040.

3. Walsh, G., Biopharmaceutical benchmarks 2018. Nat Biotechnol, 2018. 36(12): p. 1136-1145. DOI: $10.1038 /$ nbt.4305.

4. Zaman, R., et al., Current strategies in extending half-lives of therapeutic proteins. Journal of Controlled Release, 2019. 301: p. 176-189. DOI: 10.1016/j.jconrel.2019.02.016.

5. Kintzing, J.R., M.V. Filsinger Interrante, and J.R. Cochran, Emerging Strategies for Developing Next-Generation Protein Therapeutics for Cancer Treatment. Trends Pharmacol Sci, 2016. 37(12): p. 993-1008. DOI: 10.1016/j.tips.2016.10.005.

6. Moncalvo, F., M.I.M. Espinoza, and F. Cellesi, Nanosized Delivery Systems for Therapeutic Proteins: Clinically Validated Technologies and Advanced Development Strategies. Frontiers in Bioengineering and Biotechnology, 2020. 8: p. 22. DOI: 10.3389/fbioe.2020.00089.

7. Guichard, M.-J., et al., PEGylation of Recombinant Human Deoxyribonuclease I Provides a LongActing Version of the Mucolytic for Patients with Cystic Fibrosis. Advanced Therapeutics. n/a(n/a): p. 2000146. DOI: 10.1002/adtp.202000146.

8. Hertel, S.P., G. Winter, and W. Friess, Protein stability in pulmonary drug delivery via nebulization. Advanced Drug Delivery Reviews, 2015. 93: p. 79-94. DOI: 10.1016/j.addr.2014.10.003.

9. Labiris, N.R. and M.B. Dolovich, Pulmonary drug delivery. Part I: physiological factors affecting therapeutic effectiveness of aerosolized medications. Br J Clin Pharmacol, 2003. 56(6): p. 58899. DOI: 10.1046/j.1365-2125.2003.01892.x.

10. Osman, N., et al., Carriers for the targeted delivery of aerosolized macromolecules for pulmonary pathologies. Expert Opinion on Drug Delivery, 2018. 15(8): p. 821-834. DOI: 10.1080/17425247.2018.1502267.

11. Guichard, M.J., et al., Production and characterization of a PEGylated derivative of recombinant human deoxyribonuclease I for cystic fibrosis therapy. International Journal of Pharmaceutics, 2017. 524(1-2): p. 159-167. DOI: 10.1016/j.ijpharm.2017.03.057.

12. Koussoroplis, S.J., et al., PEGylation of antibody fragments greatly increases their local residence time following delivery to the respiratory tract. Journal of Controlled Release, 2014. 187: p. 91-100. DOI: 10.1016/j.jconrel.2014.05.021.

13. Freches, D., et al., PEGylation prolongs the pulmonary retention of an anti-IL-17A Fab' antibody fragment after pulmonary delivery in three different species. Int J Pharm, 2017. 521(1-2): p. 120-129. DOI: 10.1016/j.ijpharm.2017.02.021.

14. Patil, H.P., et al., Fate of PEGylated antibody fragments following delivery to the lungs: Influence of delivery site, PEG size and lung inflammation. Journal of Controlled Release, 2018. 272: p. 62-71. DOI: 10.1016/j.jconrel.2017.12.009.

15. Cantin, A.M., et al., Polyethylene glycol conjugation at Cys232 prolongs the half-life of alpha1 proteinase inhibitor. Am J Respir Cell Mol Biol, 2002. 27(6): p. 659-65. DOI: 10.1165/rcmb.4866.

16. Mahri, S., et al., Biodistribution and elimination pathways of PEGylated recombinant human deoxyribonuclease I after pulmonary delivery in mice. Journal of controlled release : official journal of the Controlled Release Society, 2020. DOI: 10.1016/j.jconrel.2020.10.034.

17. Kovaliov, M., et al., Grafting strategies for the synthesis of active DNase I polymer biohybrids. European Polymer Journal, 2018. 107: p. 15-24. DOI: 10.1016/j.eurpolymj.2018.07.041. 
18. Guichard, M.J., T. Leal, and R. Vanbever, PEGylation, an approach for improving the pulmonary delivery of biopharmaceuticals. Current Opinion in Colloid \& Interface Science, 2017. 31: p. 4350. DOI: 10.1016/j.cocis.2017.08.001.

19. Patton, J.S., C.S. Fishburn, and J.G. Weers, The lungs as a portal of entry for systemic drug delivery. Proc Am Thorac Soc, 2004. 1(4): p. 338-44. DOI: 10.1513/pats.200409-049TA.

20. Gould, J.C., et al., Bioavailability of protein therapeutics in rats following inhalation exposure: Relevance to occupational exposure limit calculations. Regulatory Toxicology and Pharmacology, 2018. 100: p. 35-44. DOI: 10.1016/j.yrtph.2018.10.003.

21. Pfister, T., et al., Bioavailability of Therapeutic Proteins by Inhalation-Worker Safety Aspects. Annals of Occupational Hygiene, 2014. 58(7): p. 899-911. DOI: 10.1093/annhyg/meu038.

22. Niven, R.W., et al., PULMONARY ABSORPTION OF POLYETHYLENE GLYCOLATED RECOMBINANT HUMAN GRANULOCYTE-COLONY-STIMULATING FACTOR (PEG RHG-CSF). Journal of Controlled Release, 1994. 32(2): p. 177-189. DOI: 10.1016/0168-3659(94)90056-6.

23. McLeod, V.M., et al., Optimal PEGylation can improve the exposure of interferon in the lungs following pulmonary administration. J Pharm Sci, 2015. 104(4): p. 1421-30. DOI: 10.1002/jps.24353.

24. Vanbever, R., Performance-driven, pulmonary delivery of systemically acting drugs. Drug Discovery Today: Technologies, 2005. 2(1): p. 39-46. DOI: 10.1016/j.ddtec.2005.05.016.

25. Lombry, C., et al., Alveolar macrophages are a primary barrier to pulmonary absorption of macromolecules. Am J Physiol Lung Cell Mol Physiol, 2004. 286(5): p. L1002-8. DOI: 10.1152/ajplung.00260.2003.

26. Gursahani, H., et al., Absorption of Polyethylene Glycol (PEG) Polymers: The Effect of PEG Size on Permeability. Journal of Pharmaceutical Sciences, 2009. 98(8): p. 2847-2856. DOI: 10.1002/jps.21635.

27. Freches, D., et al., Preclinical evaluation of topically-administered PEGylated Fab' lung toxicity. Int J Pharm X, 2019. 1: p. 100019. DOI: 10.1016/j.ijpx.2019.100019.

28. Wanner, A., M. Salathé, and T.G. O'Riordan, Mucociliary clearance in the airways. Am J Respir Crit Care Med, 1996. 154(6 Pt 1): p. 1868-902. DOI: 10.1164/ajrccm.154.6.8970383.

29. Kirch, J., et al., Mucociliary clearance of micro- and nanoparticles is independent of size, shape and charge--an ex vivo and in silico approach. J Control Release, 2012. 159(1): p. 128-34. DOI: 10.1016/j.jconrel.2011.12.015.

30. Sinicropi, D., et al., Colorimetric determination of DNase I activity with a DNA-methyl green substrate. Anal Biochem, 1994. 222(2): p. 351-8. DOI: 10.1006/abio.1994.1502.

31. Li, L., et al., The effect of the size of fluorescent dextran on its endocytic pathway. Cell Biol Int, 2015. 39(5): p. 531-9. DOI: 10.1002/cbin.10424.

32. Kooistra, T., M.K. Pratten, and K.E. Williams, Endocytosis of simple proteins by rat yolk sacs and by rat peritoneal macrophages incubated in vitro. Acta Biol Med Ger, 1981. 40(10-11): p. 163746.

33. Cingolani, E., et al., In vitro investigation on the impact of airway mucus on drug dissolution and absorption at the air-epithelium interface in the lungs. Eur J Pharm Biopharm, 2019. 141: p. 210-220. DOI: 10.1016/j.ejpb.2019.05.022.

34. Alqahtani, S., et al., Development of an In Vitro System to Study the Interactions of Aerosolized Drugs with Pulmonary Mucus. Pharmaceutics, 2020. 12(2). DOI: 10.3390/pharmaceutics12020145.

35. Braeckmans, K., et al., Three-Dimensional Fluorescence Recovery after Photobleaching with the Confocal Scanning Laser Microscope. Biophysical Journal, 2003. 85(4): p. 2240-2252. DOI: 10.1016/S0006-3495(03)74649-9.

36. Patton, J.S., Mechanisms of macromolecule absorption by the lungs. Advanced Drug Delivery Reviews, 1996. 19(1): p. 3-36. DOI: 10.1016/0169-409x(95)00113-I. 
37. Ducreux, J., et al., PEGylation of anti-sialoadhesin monoclonal antibodies enhances their inhibitory potencies without impairing endocytosis in mouse peritoneal macrophages. Bioconjug Chem, 2009. 20(2): p. 295-303. DOI: 10.1021/bc800390g.

38. Williams, K.E., et al., Quantitative studies of pinocytosis. II. Kinetics of protein uptake and digestion by rat yolk sac cultured in vitro. J Cell Biol, 1975. 64(1): p. 123-34. DOI: 10.1083/jcb.64.1.123.

39. Lucero, D., et al., Interleukin 10 promotes macrophage uptake of HDL and LDL by stimulating fluid-phase endocytosis. Biochimica Et Biophysica Acta-Molecular and Cell Biology of Lipids, 2020. 1865(2): p. 15. DOI: 10.1016/j.bbalip.2019.158537.

40. Hastings, R.H., et al., Cellular uptake of albumin from lungs of anesthetized rabbits. Am J Physiol, 1995. 269(4 Pt 1): p. L453-62. DOI: 10.1152/ajplung.1995.269.4.L453.

41. Longoni, D., et al., Interleukin-10 increases mannose receptor expression and endocytic activity in monocyte-derived dendritic cells. Int J Clin Lab Res, 1998. 28(3): p. 162-9. DOI: $10.1007 /$ s005990050037.

42. Elbert, K.J., et al., Monolayers of human alveolar epithelial cells in primary culture for pulmonary absorption and transport studies. Pharm Res, 1999. 16(5): p. 601-8. DOI: 10.1023/a:1018887501927.

43. Matsukawa, Y., et al., Size-Dependent Dextran Transport across Rat Alveolar Epithelial Cell Monolayers. Journal of Pharmaceutical Sciences, 1997. 86(3): p. 305-309. DOI: 10.1021/js960352x.

44. Buckley, C.M. and J.S. King, Drinking problems: mechanisms of macropinosome formation and maturation. Febs j, 2017. 284(22): p. 3778-3790. DOI: 10.1111/febs.14115.

45. Pratten, M.K. and J.B. Lloyd, Effects of temperature, metabolic inhibitors and some other factors on fluid-phase and adsorptive pinocytosis by rat peritoneal macrophages. Biochem J, 1979. 180(3): p. 567-71. DOI: 10.1042/bj1800567.

46. Lloyd, J.B. and K.E. Williams, NON-SPECIFIC ADSORPTIVE PINOCYTOSIS. Biochemical Society Transactions, 1984. 12(3): p. 527-528. DOI: 10.1042/bst0120527.

47. Mathia, N.R., et al., Permeability characteristics of calu-3 human bronchial epithelial cells: in vitro-in vivo correlation to predict lung absorption in rats. J Drug Target, 2002. 10(1): p. 31-40. DOI: 10.1080/10611860290007504.

48. Verhoef, J.J. and T.J. Anchordoquy, Questioning the Use of PEGylation for Drug Delivery. Drug Deliv Transl Res, 2013. 3(6): p. 499-503. DOI: 10.1007/s13346-013-0176-5.

49. Patel, B., V. Gupta, and F. Ahsan, PEG-PLGA based large porous particles for pulmonary delivery of a highly soluble drug, low molecular weight heparin. J Control Release, 2012. 162(2): p. 31020. DOI: 10.1016/j.jconrel.2012.07.003.

50. Sanders, N., et al., Extracellular barriers in respiratory gene therapy. Adv Drug Deliv Rev, 2009. 61(2): p. 115-27. DOI: 10.1016/j.addr.2008.09.011.

51. Livesey, G. and K.E. Williams, Rates of pinocytic capture of simple proteins by rat yolk sacs incubated in vitro. Biochem J, 1981. 198(3): p. 581-6. DOI: 10.1042/bj1980581.

52. Yamamoto, T., et al., Interaction of poly(ethylene glycol)-conjugated phospholipids with supported lipid membranes and their influence on protein adsorption. Science and Technology of Advanced Materials, 2016. 17(1): p. 677-684. DOI: 10.1080/14686996.2016.1240006.

53. Button, B., et al., A periciliary brush promotes the lung health by separating the mucus layer from airway epithelia. Science, 2012. 337(6097): p. 937-41. DOI: 10.1126/science.1223012.

54. Kirch, J., et al., Optical tweezers reveal relationship between microstructure and nanoparticle penetration of pulmonary mucus. 2012. 109(45): p. 18355-18360. DOI: 10.1073/pnas.1214066109 \%J Proceedings of the National Academy of Sciences.

55. Rubin, B.K., Mucus structure and properties in cystic fibrosis. Paediatr Respir Rev, 2007. 8(1): p. 4-7. DOI: 10.1016/j.prrv.2007.02.004. 
56. Todoroff, J. and R. Vanbever, Fate of nanomedicines in the lungs. Current Opinion in Colloid \& Interface Science, 2011. 16(3): p. 246-254. DOI: 10.1016/j.cocis.2011.03.001. 